\title{
Analisis Penerapan Model Pembelajaran Student Centered Learing Dengan Media Daring Pada Mata Kuliah Auditing (Studi Kasus Pada Mahasiswa Akuntansi Universitas Potensi Utama)
}

Analysis of the Application of the Student Centered Learning Model Using Online Media in Auditing Courses (Case Study on Accounting Students in Universitas Potensi utama)

\section{Ridho Gilang Adiko}

Fakultas Ekonomi dan Bisnis, Program Studi Akuntansi, Univesitas Potensi Utama, Jl. K.L.Yos Sudarso, Tj.Mulia,Medan Deli, Kota Medan20241 Telp (061)6640525 Email:ridho.rig ia@g mail.com

\begin{abstract}
ABSTRAK
Tujuan penelitian ini adalah untuk mengetahui dan menganalisis peranan model pembelajaran Student Centered Learning dengan media daring pada mata kuliah auditing(studi kasus pada mahasiswa akuntansi universitas potensi utama). Jenis dan sumber data yang digunakan dalam penelitian ini adalah data primer dan data sekunder. Teknik analisis data yang digunakan dalampenelitian ini adalah dengan observasi dan wawancara. Jumlah populasi dalam penelitian ini berjumlah 96 orang, dan sampel penelitiannya berjumlah 20 orang. Pandemi covid yang melanda seluruh dunia termasuk Indonesia, mau tidak mau mengakibatkan proses belajar mengajar yang biasanya dilakukan secara langsung atau tatap muka, menjadi dilakukan secara daring atau menggunakan jaringan internet dan teknologi. Kehidupan new normal dengan kebiasaan baru dan metode belajar yang baru berupa daring tidak serta merta berjalan dengan mulus. Banyak sekali kendala dan hambatan yang dirasakan, seperti kemampuan menggunakan teknologi, sinyal yang tidak baik, kuota yang terbatas, serta kemampuan materi yang juga terbatas. Kemampuan menyerap dan memahami materi dengan media daring juga memiliki banyak kendala. Kesalahn persepdi dari mahasiswa, kurang jelasnya penejelasan dosen, serta terbatasnya waktu untuk diskusi menyebabkan jasil akhir belajar yang kurang maksimal. Karena itulah model pembelajaran Student Centered Learning diharapkan mampu menutupi kekurangan selama proses pembelajaran daring demi memaksimalkan kegiatan pembelajaran auditing.
\end{abstract}

Kata Kunci : Model pembelajaran Student Centered Learning, media daring, auditing

\section{ABSTRACT}

The purpose of this study was to identify and analyze the role of the Student Centered Learning model with online media in auditing courses (case studies of major potential university accounting students). The types and sources of data used in this study are primary data and secondary data. The data analysis technique used in this study was observation and interviews. The total population in this study amounted to 96 people, and the research sample amounted to 20 people. The covid pandemic that has hit the whole world, including Indonesia, has inevitably resulted in the teaching and learning process, which is usuallydone in person or face-to-face, to be done online or using the internet and technology. The new normal life with new habits and new learning methods in the form of online does not necessarily run smoothly. There are so many obstacles and obstacles that are felt, such as the ability to use technology, poor signal, limited quota, and limited material capabilities. The ability to absorb and understand material using online media also has many obstacles. Misperceptions from students, lack of clarity in explanations from lecturers, and limited time for discussion caused the final learning outcomes to be less than optimal. That's why the Student Centered Learning learning model is expected to be able to cover deficiencies during the online learning process in order to maximize auditing learning activities.

Keywords : Student Centered Learning model, online media, auditing 


\section{PENDAHULUAN}

Menurut Undang-undang Republik Indonesia Nomor 20 tahun 2003 mengenai Sistem Pendidikan Nasional, menyatakan bahwa pembelajaran merupakan sebuah proses interaksi antara pendidik dengan peserta didik dengan sumber belajar yang berlangsung dan terjadi dalam suatu lingkungan belajar. Secara umum, proses pembelajaran dilihat sebagai suatu kegiatan yang menghasilkan interaksi atau melibatkan komponen-komponen utama, yaitu para peserta didik, pendidik, dan sumber belajar yang dimana kegiatan ini berlangsung dalam suatu lingkungan belajar.

Banyak sekali model pembelajaran yang berkembang di dunia pendidikan hingga sekarang ini. Inovasi yang dilakukan para pendidik demi meningkatkan kualitas mengajar sangatlah berperan penting dalam memjaukan dunia pendidikan, terutama agar para siswa atau mahasiswa yang diajar mudah memahami materi yang disampaikan. Pada masa pandemi covid-19 ini, tentulah para praktisi mengajar seperti para dosen harus pintar menerapkan model pembelajaran yang mampu merangsang kreatifitas dan semangat mahasiswa dalam proses pembelajaran daring. Mengapa demikian? Sebab tidak dapat dipungkiri bahwasannya proses pembelajaran dengan media daring ini jika dijalankan tanpa ada inovasi model pembelajaran tentu akan sangat membosankan. Bukan tidak mungkin para mahasiswa enggan bersemangat mengikuti proses belajar dan akhirnya tidak mampu menyerap ilmu yang disampaikan. Keterbatasan komunikasi pada masa pandemi ini benar-benar sangat menguras fisik dan mental para pengajar dan murid yang diajar. Susahnya komunikasi karena keterbatasan sinyal dan kuota, serta keterbatasan akses bertanya dan lainnya menyebabkan banyak materi yang tidak tersampaikan dengan baik. Terutama pada mata kuliah auditing yang diambil oleh para mahasiswa akuntansi di universitas potensi utama, yang harus banyak menuntut keaktifan mahasiswa, dan tidak hanya bergantung pada penjelasan dosen saja. Karena jika selama 16 pertemuan perkuliahan dosne hanya menggunakan metode ceramah tanpa melibatkan keaktifan mahasiswa, maka bisa dipastikan mahasiswa akan snagat merasa bosan dan jenuh dalam mengikuti perkuliahan, yang akhirnya mengakibatkan ketidakseriusan mereka dalam belajar. Model pembelajaran Student Centered Learning atau model pembelajaran yang berpusat pada mahasiswa diterapkan dengan tujuan agar mahasiswa ikut serta aktif dalam kegiatan proses pembelajaran, bahkan model pembelajaran ini menuntut keaktifan mahasiswa lebih besar dari pengajar. Dalam mata kuliah auditing, keaktifan yang diharapkan bukan hanya sekedar bertanya dan menjawab saja, namun kemampuan menganalisis, menysuusn jawaban dan mengaitkan permasalahan atau kasus pada kehidupan sehari-hari sehingga para mahasiswa mampu mengembangkan teori dan permasalahan yang sedang dipecahkan.

Proses pembelajaran dengan menggunakan Student Centered Learning ini diharapkan mampu merangsang semangat dan keaktifan mahasiswa untuk berlomba-lomba memberikan hasil belajar yang terbaik pada setiap sesi pertemuan proses belajar. Sehingga, meskipun perkuliahan dilaksanakan daring, namun mampu mencapai tujuan pembelajaran yang telah disusun sebelumnyya dan membuat suasana pembelajaran menyenangkan. Namun pelaksanaan dengan metode SCL ini tetap harus mendapat pantauan langsung dari dosen pengampu matakuliah, guna meluruskan informasi- informasi yang telah diperoleh oleh para mahasiswa, dan untuk menjadi wadah diskusi para mahasiswa mengenai hal - hal yang masih kurang difahami.

\section{A. Rumusan Masalah}

Adapun yang menjadi rumusan masalah dalam penelitian ini adalah :

1. Apakah model pembelajaran student centered learning dengan media daring efektif untuk dilakukan selama pandemi covid-19?

2. Apa saja kendala yang dihadapi oleh para dosen maupun mahasiswa selama proses pembelajaran daring?

3. Apa saja upaya yang bisa dilakukan untuk meminimalisasi kendala yang ada selama proses daring ? 


\section{B. Tujuan Penelitian}

Adapun tujuan penelitian yang ingin dicapai oleh peneliti dalam penelitian ini adalah sebagai berikut :

1. Untuk mengetahui dan menganalisis efektivitas penerapan model pembelajaran stundent centered learning dengan media daring pada mata kuliah auditing

2. Untuk mengetahui dan menganalisis kendala yang dihadapi selama pembelajaran daring

3. Untuk mengetahui dan menganalisis kekurangan dan kelebihan dari penerapan model belajar Student Centered Learning

4. Untuk menegtahui dan menganalisis upaya dalam meminimalis ir kendala yang ada

\section{LANDASAN TEORI}

\section{A. Pengertian Model Pembelajaran Student Centered Learning}

Seperti yang telah dijabarkan sebelumnya bahwaannya model pembelajaran Student Centered Learning merupakan model pembalajran yang berpusat pada mahasiswa dengan tujuan agar maahasisw alebih aktif dan kritis selama proses belajar. Jadi ketik dosen selesai dalam memaparkan materi, maka diharpkan para mahasiswa mampu untuk menjelaskan kembali apa yang difahaminya, bertanya, menjawab, dan menganalisis setiap soal yang diberikan.

Berikut pendapat beberapa ahli mengenai pegertian dari Student Centered Learning atau pembelajaran yang berpusat pada siswa:

1) Aipni (2013) mengatakan bahwa model pembelajaran Student Centered Learning (SCL) adalah model pembelajaran yang menempatkan peserta didik sebagai objek pembelajaran yang diharpkan mampu bersikap aktif , mandiri, bertanggungjawab, kreatif, dan berinisiatif dalam menerima materi yang diajarkan.

2) Menurut Zulvia trinova (2013) model pembelajaran Student Centered Learning adalah model pembelajaran yang paling diminati di dunia pendidikan sekarang ini dan proses pembelajaran ini lebih memfokuskan kepada mahasiswa sebagai peserta didik.

3) Sedangkan Azizah (2010) mengatakan bahwa dengan menrapkan model pembelajaran SCL makan mahasiswa akan mampu menemuka gaya belajar yang paling nyaman menurut mereka sendiri sehingga dapat memotivasi dalam proses belajar mengajar.

Dari pernyataan beberpa para ahli diatas, maka dapat disimpulkan bahwasannya model pembelajaran Studentcentered learning merupakan model pembelajaran yang berfokus pada mahasiswa, dalam artian keaktifan mahasiswa dalam belajar dan mencari tahu mengenai informasi-informasi baru lebih besar porsinya dibandingkan dosen yang berceramah. Hal ini dilakukan agar mahasiswa lebih aktif, kreatif, dan berinisiatif dalam proses belajar, tidak hanya menunggu dan menerima ilmu dari dosen, menengar ceramah dosen saja, tetapi ikut serta dalam mencari tahu kebenaran mengenai suatu informasi dan ilmu pengetahuan.

\section{B. Kelebihan Dan Kelemahan Student Centered Learning}

Dalam pelaksanannya, model pembelajaran SCL tidak selalu mulus. Ada beberapa kelebihan dan kekurangan dari metode ini menurut Setiadji(2010), yaitu:

\section{Kelebihan:}

1) Mengaktifkan cara berfikir kritis mahasiswa dalam proses belajar

2) Mampu mendorong mahasiswa untuk lebih semangat menguasai materi yang diajarkan dalam proses discovery maupn inquiry

3) Mahasiswa mampu mengeksplor dan menemukan gaya belajar mereka sendiri sesuai dengan karakteristik mereka 
4) Mampu mengembangkan kemampuan mahasiswa untuk lebih kreatif dalam memecahkan masalah dan mengembangkannya

5) Mampu memenuhi latar belakang pembelajaran

\section{Kekurangan:}

1) Memiliki kesulitan untuk pengimplementasiannya pada kelas besar

2) Membutuhkan waktu yang relatif lebih lama

3) Tidak cocok untuk mahasiswa yang malas dan tidak mandiri

\section{Indikator Pengukur Model Pembelajatan Student Centered Learning}

Dalam pelaksanannya tebtu ada beberapa indikator yang perlu diperhatikan dalam mengukur keberhasilan penerapan model pembelajaran SCL, yaitu :

1) Keaktifan adapun keaktifan yang dimaksud adalah berupa inisiatif dan kreatifitas mahasiswa dalam proses belajar, baik aktif dalam bertanya, menjawab, mengerjakan kasus, dan sebagainya. Dengan adanya metode SCL ini diharapkan mahasiswa lenih aktif dalam mencari tahu, menjawab, dan mengkomunikasikan hal - hal yang dirasa penting, baik kepada dosen ataupun kepada teman sekelas.

2) Kolabratif disini mahasiswa dituntut untuk mampu saling berkolaborasi dengan segala unsur yang mendukung proses pembelajaran, baik itu berkolaborasi dengan teman sekelas, teknologi ataupun dosen.

3) Konstruktif artinya mahasiswa harus mampu membangun ide - ide cemerlang, pemikiran baru, dan daya pikir yang inovatif guna pembaharuan informasi dan perkembangan ilmu pengetahuan.

4) Antusiastik dalam proses pembelajaran, tentu sikap semangat dan antusias mahasiswa sangat dibutuhkan. Jika mahasiswa semangat menyambut kelas yang akan kita ajarkan, sudah dipastikan mereka siap untuk menerima materi yang akan kita ajarkan.

5) Dialogis artinya disini para mahasiswa harus cakap dalam berkomunikasi dan menjawab semua pertanyaan dengan baik dan benar serta bijak. Dibutuhkan kecakapan dalam berkomunikasi agar tidka terjadi kesalahfahaman atau berbeda persepsi antar mahasiswa maupun dosen.

6) Kontekstual

Dalam hal ini mahasiswa dituntut harus mampu mengerti, memahami, dan mempelajari materi sesuai dengan konteksnya.

7) Multisensory

artinya dalam proses belajar para mahasiswa haru smampu menggunakan semua fungsi panca inderanya dengan baik, untuk mendukung keberhasilan proses belajar. Seperti menggunakan mata dengan baik untuk embaca, telinga untuk mendengarkan informasi, mulut untuk menjawab dan bertanya, jari - jari digunakan untuk mencatat dan semua panca indera lainnya.

8) Konseptual

Pada indikator ini, mahasiswa diharapkan mampu memahami materi dan permasalahan secara konsep, namun tetap dikembangkan dengan pemikiran dan olah kata oleh mahasiswa itu sendiri.

9) High order thingking: artinya dengan metode SCL ini mahasiswa harus mampu berfikir dengan kritis, logis, reflektif, metakognitif, dan berpikir kreatif yang merupakan kemampuan berpikir tingkat tinggi. Pada tahap HOT ini, para mahasiswa sudah mampu berfikir kritis secara global, bahkan mencipta atau menghasilkan sesuatu baik ilmu baru ataupun produk dari hasil proses belajar yang ia lakukan. Dan proses pemikiran secara High order thingking ini sekarang sedang digalakkan oleh pemerintah dalam Merdeka belajar-kampus merdeka. 


\section{Media Pembelajaran Daring}

Menurut Undang-undang Republik Indonesia Nomor 20 tahun 2003 mengenai Sistem Pendidikan Nasional, menyatakan bahwasannya pembelajaran merupakan sebuah proses interaksi antara pendidik atau pengajar dengan peserta didik dan kegiatan belajar ini berlangsung dalam suatu lingkungan pendidikan.

Hamalik dalam Fakhrurrazi (2018: 86) mengatakan bahwa pembelajaran merupakan suatu kegiatan yang telah disusun rapi tatanan kegiatannya yang di dalamnya terdapat unsur manusiawi (guru dan peserta didik), material( buku, papan tulis, spidol, kapor dan lainnya), fasilitas (ruang kelas, audio visual), dan proses belajar yang saling mempengaruhi satu sam alain demi mencapai tujuan pembelajaran.

Dalam pelaksanaan pembelajaran di era covid-19, masyarakat Indonesia mengenal istilah baru yaitu pembelajaran degan media daring. Bukan hanya istilahnya yang terasa asing, namun ternyata pelaksanaan daring ini juga sangat awam bagi banyak para pengajar, baik yang usia muda ataupun yang usia tua. Kecakapan dalam menggunakan teknologi sangat dituntut dalam proses belajar daring. Bila seorang pengajar sudah berusia tua dan sulit memahami teknologi, mau tidak mau mereka tetap harus mau belajar cara penggunaan teknologi selama daring.

Begitu juga dengan para peserta didik, yang mau tidak mau harus siap secara fisik, mental, dan materi dalam proses pembelajaran daring. Begitu banyak kendala yang dirasakan selama proses pembelajaran ini. Termasuk peneliti sebagai dosen akuntansi yang mengampu mata kuliah auditing. Kesulitan dalam menjelaskan secara terinci pada mahasiswa, kesulitan mahasiswa memahami, keterbatasan waktu, kuota, jaringan, bahkan ketidak puasan dalam menjelaskan materi dibandingkan tatap muka begitu dirasakan selama pembelajaran daringn ini. Tentu ini akan sangat mempengaruhi pencapaian tujuan akhir dari proses pembelajaran. Namun demikian, baik pengajar dan peserta didik tetap secara bersama-sama memaksimalkan kegiatan daring ini agar proses belajar tetap terasa menyenangkan.

Menurut Ghirardini dalam Kartika (2018:27) mengatakan bahwa pembelajaran daring merupakan pembelajaran yang efektif yang mengolaborasi antara kegiatan belajar secara bersama-sama dengan belajar mandiri yang didalamnya ada umpan balik untuk mencapai tujuan pembelajaran.

Untuk melihat keefektifan proses pembelajaran daring, maka ada beberapa indikator pengukur variabel ini, yaitu :

1) Pengajaran daring menuntut pembelajar untuk Interaktivitas, kemandirian, aksesibilitas, konstruktiv, dialogis, aktif, dan high order thingking

2) Bahan pengajaran yang lengkap dan terususun rapi, agar materi yang disampaikan akan lebih jelas maknanya.

3) Pembelajaran Daring dapat mengatasi Keterbatasan indera, ruang dan waktu.

4) Kendala yang dihadapi saat pembelajaran daring

Dalam pelaksanaan pembelajaran dengan media daring, pemerintah mengharapkan para pendidik atau dosen menyusun terlebih dahulu rancangan belajar atau yang disebut dengan RPS guna mempermudah berjalannya proses belajar. Dengan adanya RPS ini maka mahasiswa bisa mempersiapkan diri untuk belajar materi yang akan ditemui di pertemuan selanjutnya. Karena jika tidak ada pedoman atau rancangan materi setiap pertemuan yang akan dilaksanakan, maka baik mahasiswa atau dosen tidak akan mampu mempersiapkan diri secara ilmu dan fisik untuk menerima pembelajaan yang ada. Itulah gunanya RPS sebagai acuan setiap pertemuan yang akan dilaksanakan, atau dengan kata lain sedia senjata sebelum perang. 


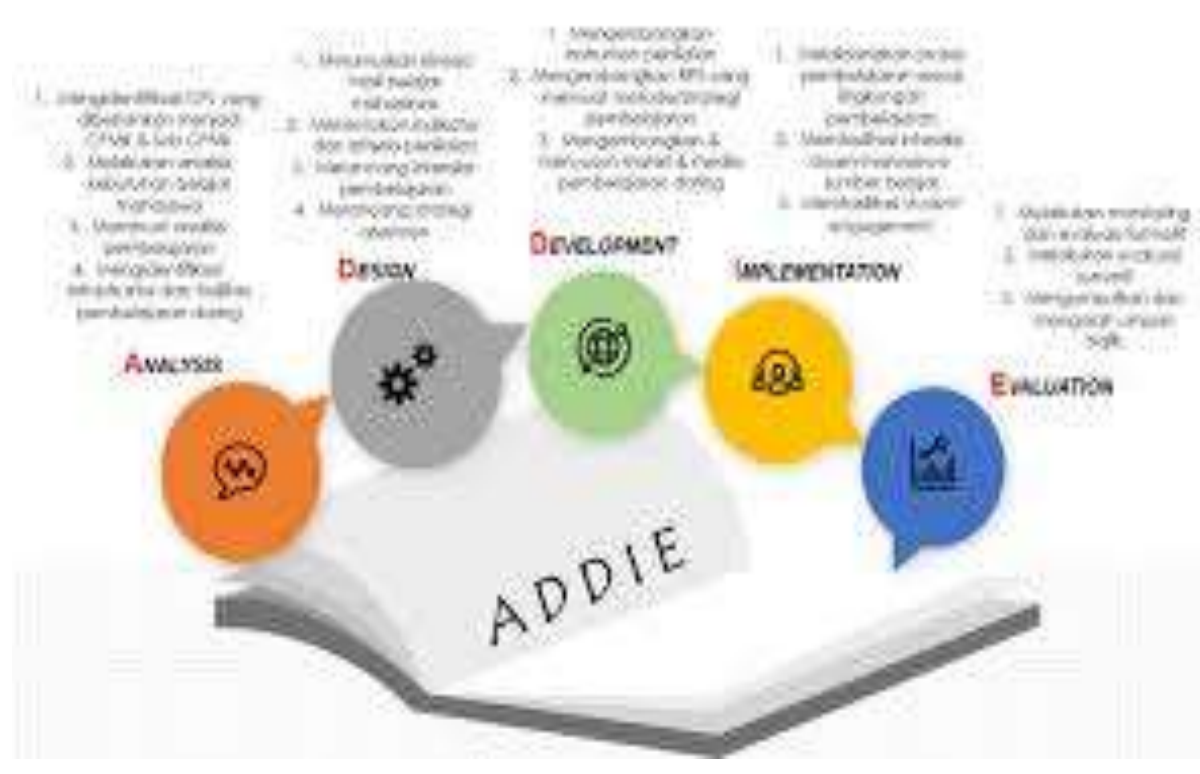

Gambar 1. Proses Belajar Daring kementerian Pendidikan Dan Kebudayaan

\section{E. Karakteristik Pembelajaran Daring}

Pembelajaran dengan media daring merupakan model pembelajaran baru yang dikenal masyarakat indonesia semenjak pandemi covid-19. Pemanfaatan jaringan internet oleh mahasiswa dalam proses pembelajaran daring dirasakan menjadi faktor utama keberhasilan proses pembelajaran daring. Pendekatan pembelajaran media daring memiliki beberapa karakteristik sebagai berikut:

a) Menuntut para peserta didik untuk membangun dan menciptakan sebuah pengetahuan secara mandiri (constructivism) dan kreatif.

b) Para peserta didik akan belajar berkolaborasi dengan peserta didik lain dalam membangun dan mengembangkan pengetahuannya dalam memecahkan masalah secara bersama-sama (social constructivism);

c) Membentuk sebuah komunitas pembelajar atau peserta didik (community of learners) yang inklusif

d) Menggunakan media laman (website) yang bisa selalu diakses melalui internet, pembelajaran berbasis teknologi dan komputer, kelas virtual, atau kelas digital

e) Interaktivitas, kemandirian, aksesibilitas, dan pengayaan oleh para peserta didik

\section{F. Indikator pengukur Efektivitas Pembalajaran daring}

Dalam setiap akhir proses pembelajaran, baik daring maupun luring, pastilah seorang dosen akan melakukan evaluasi atau penilaian terhadap hasil belajar mahasiswa yang diajar. Hal ini dilakukan untuk melihat apakah tujuan pembelajaran telah tercapai atau tidak. Disinilah fungsi media daring sangat diharapkan mampu untuk mencapai tujuan pembelajaran tersebut. Yusuf (2017) mengatakan bahwasannya ada 5 indikator untuk mengukur keberhasilan efektivitas belajar, yaitu:

1. Proses komunikasi yang baik dan dua arah terjadi antara dosen dan mahasiswa

2. Pelaksanaan pembelajaran yang dilakukan secara daring

3. Respon atau keaktifan peserta didik (mahasiswa) dalam mengikuti proses pembelajaran daring ini.

4. Tinggi rendahnya Aktivitas belajar mahasiswa selama proses pembelajaran

5. Hasil belajar yang dievaluasi dan dinilai setiap akhir pertemuan 
Dalam praktiknya, proses daring ini bisa menggunakan banyak aplikasi sebagai media pembelajaranannya, seperti zoom, google meet, google classroom, e-learning, dan sebagainya. Jadi para mahasiswa dan dosen harus semaksimal mungkin menggunakan berbagai aplikasi pembelajaran daring, guna mencapai tujuan pembelajaran yang diinginkan.

\section{G. Audit}

Menurut PSAK (2006) Audit merupakan suatu proses analisis yang sistematis dan objektif untuk memperoleh informasi tentang aktivitas ekonomi yang kemudian akan dianalisis dan dievaluasi kebenarannya guna mneghasilkan asersi atau keputusan hasil audit. Sukrisno Agoes (2012:2) menyatakan bahwa audit merupakan hasil astetasi atau hasil audit yang dikemukakan oleh seorang expert atau auditor tentang realibilitas pernyataan atau temuan yang ia dapatkan dilapangan. Dengan demikian peneliti menyimpulkan bahwa audit merupakan kegiatan yang dilakukan secara sistematis, tertata, dan terprosedur oleh seseorang yang kompeten, ahli, dan independen dibidangnya, guna menghasilkan laporan audit yang berkualitas.

Menurut Sukrisno Agoes (2014) menjelaskan tentang jenis-jenis auditing yang umum dilaksanakan, yaitu :

1. Audit Operasional

Merupakan kegiatan audit yang bertujuan untuk memeriksa kegiatan keseluruhan operasional atau aktivitas perusahaan berdasarkan standar operasional perusahaan untuk melihat efesiensi, efektifitas, dan ekonomisasinya.

2. Compliance audit (audit Ketaatan)

Merupakan kegiatan pemeriksaan yang dilakukan oleh seorang audtor untuk melihat apakah peraturan good coorporate governance perusahaan telah ditaati dan dilaksanakan sesuai prosedur oleh para karyawan yang bekerja.

3. Financial Audit (Audit Atas Laporan Keuangan)

Merupakan kegiatan audit yang paling sering kita dengan dan temui pada kasus audit mata kuliah auditing. Audit laporan keuangan dilakukan dengan tujuan untuk menilai apakah laporan keuangan yang disusun perusahaan sedah benar sesuai SAK, dan sesuai bukti transaksi yang ditemukan auditor

\section{H. Kerangka Konseptual Penelitian}

Seperti yang telah dijabarkan sebelumnya bahwasannya penerapan model pembelajaran student centered learning selama masa daring diharapkan mampu meningkatkan kualitas, semangat, dan motivasi mahasiswa dalam mengikuti perkuliahan terutama mata kuliah daring. Sebab dengan variatif model pembelajaran ini diharapkan mampu menghidupkan suasana belajar yang menyenangkan dan mampu menstimulasi keaktifan mahasiswa. Berikut gambar kerangka konseptualnya :

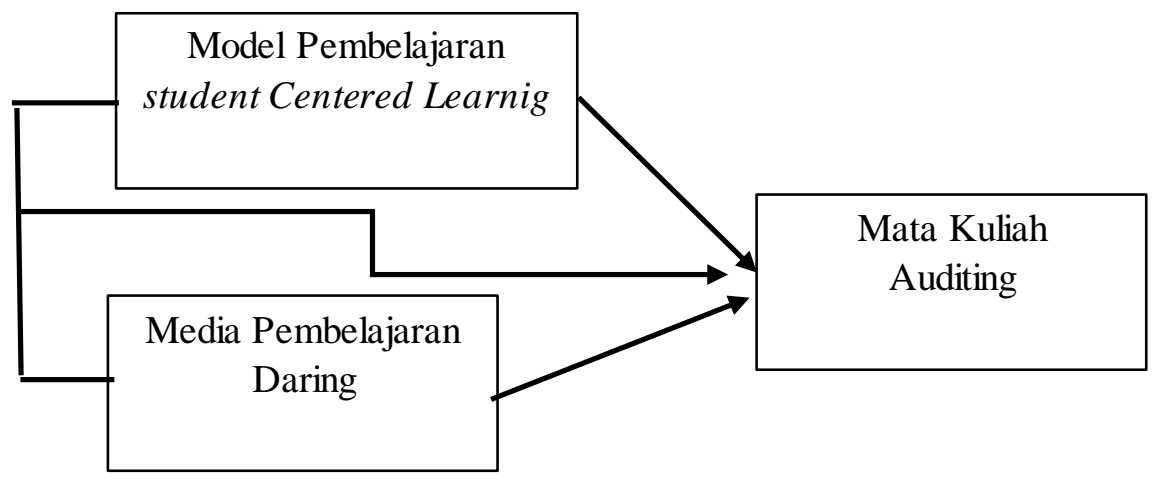

Gambar 2. Kerangka Konseptual 


\section{METODOLOGI PENELITIAN}

\section{A. Jenis Data}

Adapun jenis data yang digunakan dan diperoleh oleh peneliti dalam penelitian ini adalah sebagai berikut:

1) Data Primer

Adalah data yang diperoleh langsung oleh penulis dari sumber datanya. Data primer disebut juga sebagai data asli atau data baru terkini. Untuk mendapatkan data primer, penulis harus mengumpulkannya secara langsung. Adapun sumber data primer dari penelitian ini adalah mahasiswa akuntansi semester 4 kelas pagi dan malam yang berjumlah 96 orang.

2) Data Sekunder

Data sekunder ysng peneliti peroleh dari berbagai sumber seperti buku, jurnal, informasi perusahaan maupun internet.

\section{B. Populasi dan Sampel}

Adapun yang menjadi populasi dalam penelitian ini adalah para mahasiswa akuntansi semester 4 yang mengikuti mata kuliah auditing kelas pagi dan malam dan berjumlah 96 orang. Untuk pengambilan sampel dilakukan dengan metode random sampling, yaitu dengan mewawancarai sekitar 20 orang mahasiswa.

\section{Metode Pengumpulan Data}

Dalam melaksanakan penelitian ini, data dan informasi dikumpulkan dengan menggunakan beberapa teknik pengumpulan data, yaitu:

a) Observasi

Observasi yang dilakukan oleh penulis adalah dengan mengamati dan menganalisis permasalahan yang terjadi pada mahasiswa akuntansi yang mengikuti mata kuliah auditing.

b) Wawancara (interview)

Pengumpulan data yang digunakan oleh penulis untuk mendapatkan informasi dengan melakukan tanya jawab atau wawancara secara lisan dan tatap muka dengan para mahasiswa yang menjadi sampel penelitian.

\section{Metode Analisis Penelitian}

Metode analisis yang digunakan oleh penulis adalah metode deskriptif, yaitu dengan cara menentukan, mengumpulkan data, mengklasifikasikan dankemudian membandingkan dengan teoriteori, lalu diambil suatu kesimpulan dan selanjutnya diberikan saran.

\section{E. Waktu Penelitian}

Dalam penelitian ini untuk melengkapi bahan penulisan, maka penelitian dilaksanakan mulai bulan April 2021 sampai dengan bulan Mei 2021

\section{HASIL DAN PEMBAHASAN}

Penelitian ini diharpkan mampu menjadi bahan evaluasi bagi para tenaga pengajar yang melakukan proses belajar dengan media daring pada mata kuliah auditing. Bukan hal yang mudah mengajarkan materi auditing yang terdiri dari konsep teoritis dan praktik dalam pemecahan kasus atau case method dengan media daring. Penyampaian informasi yang salah oleh para mahasiswa bisa mengakibatkan keambiguan dari apa yang difahami oleh dosen dan mahasiswa. Itulah sebabnya

dibutuhkan banyak sekali metode atau model pembelajaran yang harus diterapkan dan dikombinasikan oleh para dosen termasuk saya sendiri dalam mengampu mata kuliah auditing. Tujuannya agar proses daring ini tidak sekedar berjalan , namun harus menghasilkan evaluasi yang 
baik setiap akhir pembelajaran.

Seperti yang dijelaskan sebelumnya di kajian pustaka bahwasannya model pembelajaran Student Centered Learning merupakan salah satu model pembelajaran yang saat ini sangat digemari oleh para pendidik dalam proses mengajar. Karena tidak seperti zaman dahulu, dimana seorang pengajar memiliki porsi penuh dalam menjelaskan, atau biasa dikenal dengan metode ceramah. Metode ceramah ini snagat tidak cocok digunakan pada proses pemebalajaran daring, sebab akan menimbulkan rasa bosan, suntuk, vapek dan tidak dapat memicu keaktifan dan kreatifitas mahasiswa dalam berfikir dan bertindak.

Dalam setiap proses pembelajaran, para mahasiswa diharapkan dapat mengerti dan memahami materi pembelajaran dengan baik. Pemahaman dalam proses belajar berarti mahasiswa bisa menagkap, menyimak, dan memahami semua materi yang telah dijelaskan oleh dosen selama proses pembelajaran. Tanpa adanya pemahaman pada materi yang telah diajarkan, maka akan mempengaruhi tingkat pengetahuan,keterampilan,dan sikap mahasiswa tersebut. Selanjutnya, pemahaman pada para mahasiswa ini dibagi ke dalam tiga kategori, yaitu: (a) tingkat pertama atau tingka yangt terendah, yaitu pemahaman terjemahan, dalam arti memahami materi secara terjemahan atau baku ; (b) tingkat kedua adalah pemahaman berupa penafsiran, yaitu menghubungkan dan mengaitkan bagian-bagian terdahulu dengan yang diketahui sekarang atau berikutnya, atau dengan kata lain menghubungkan beberapa bagian dari grafik dengan kejadian, membedakanyang pokok dan yang bukan pokok; dan (c) pemahaman tingkat ketiga atau pemahaman tingkat tertinggi, yakni pemahaman ekstrapolasi .Berdasarkan uraian tersebut, dapat diketahui bahwa pemahaman merupakan hal terpenting dalam pembelajaran karena sebagai bentuk pernyataan hasil belajar. Maka, untuk meningkatkan pemahaman diperlukan proses belajar yang baik dan benar. Pemahaman mahasiswa akan dapat berkembang bila proses pembelajaran terlaksana dengan efektif dan efisien. Dengan demikian, dilakukanlah penelitian ini yang bertujuan untuk mengetahui hubungan media pembelajaran daring terhadap peningkatan pemahaman belajar mahasiswa akuntansi pada mata kuliah auditing di Universitas Potensi Utama. Selain itu, penelitian ini bisa menjadi salah satu rekomendasi bagi pengajar dalam pemilihan penggunaan media pembelajaran yang bisa dipahami oleh mahasiswa selama pembelajaran dimasa pandemi saat ini.

Penerapan Student Centered Learning ini bisa dilakukan dengan cara mebuat kelompok belajar atau tugas individu. Kelompok ajar ini bisa berupa small group atau big group, tergantung kebutuhan proses pembelajaran. Media daring yang digunakan juga banyak jenisnya, bisa zoom, google meet, google classroom, group whatsapp, dan sebagainya.

Begitu pula dengan peneliti sebagai dosen yang mengajarkan mata kuliah auditing yang menggunakan media daring berupa zoom, e-learning, dan group whatssapp. Dengan menggunakan model pembelajaran student centered learning makan peneliti sebagai dosen pengampu mata kuliah auditing melakukan proses belajar seperti berikut ini :

1. Setiap pertemuan akan dilakukan diskusi berupa persentase baik mengenai materi yang diajarkan atau kasus yang akan dipecahkan.yang akan dilakukan oleh tiap kelompok yang terdiri dari 2 atau 3 orang.

2. Kemudian selesai dilakukan persentase ,diakhir akan dibuka sesi tanya jawab

3. Siapa saja boleh bertanya kepada kelompok yang persentase.

4. Dimana pertanyaan tersebut bisa dijawab oleh siapa saja, bukan hanya bisa dijawab oleh pemakalah.

5. Kemudian diakhir sesi tanya jawab maka dosen akan menyuruh mahasiswa mengumpulkan tugas individu berupa merangkum hasil pembelajaran setiap pertemuan dengan menggunakan bahasa sendiri. 
Persentase yang dilakukan bisa membahas mengenai materi, kasus atau pemahaman yang sedang beredar luas dimasyarakat mengenai auditing, yang dimana sesi diskusi ini bertujuan untuk menemukan titik temu atas apa yang sedang dibahas. Namun tidak dipungkiri, proses belajar ini kadang menemukan banyak sekali kendala. Apalagi dalam auditing ada yang namanya menemukan dan menganalisis kasus. Kasus ini bisa berupa pelanggaran auditor, klien, laporan keuangan dan sebagainya. Seperti wawancara yang peneliti lakukan kepada para mahasiswa yang menjadi sampel penelitian mengatakan bahwasannya banyak sekali kendala dalam proses belajar daring ini, terutama di awal pelaksanaanya di tahun pertama era daring dan covid. Berikut beberapa kendala yang dirasa sangat menyulitkan para mahasiswa selama daring:

1) Perbedaan persepsi dalam menangkap maksud dosen oleh mahasiswa

2) Terkadang susah memahami materi jika dijelaskan secara daring karena terkendala sinyal yang tidak stabil sehingga suara terkadang hilang timbul

3) Kuota yang tiba-tiba habis ditengah sesibelajar mengakibatkan ketertinggalan pembelajaran oleh mahasiswa

4) Kesalahan teknis yang tidka terduga seperti mati lampu , hujan, badai yang menyebabkan proses belajar sangat terganggu

5) Keterbatasan waktu dalam bertanya dan ketidakpuasan mendengar penejlasan dibandingkan dnegan tatap muka

6) Keterbatasan materi yang dirasakan sangat berpengaruh selama masa covid-19

Terkadang beberapa mahasiswa yang kurang tanggap dalam memahaminya materi atau salah mengerti maksud si dosen sering menjadi pemicu kesalahan dalam menjawab tugas yang diberikan. Inilah kadang yang perlu dibenahi selama daring, diharapkan dengan menerapkan Student Centered Learning berbasis small grooup maka antar mahasiswa mampu mengajarkan temannya yang masih kurang faham untuk bersama -sama memahami dan memecahkan kasus yang diberikan, dengan pegawasan dari dosen pengampu mata kuliah tersebut. Jika dirinci ada beberapa upaya yang dapat dilakukan untuk mengatasi kendala yang ada:

1) Kecukupan kuota internet yang merata oleh pemerintah kepada para pendidik dan siswa

2) Kelayakan siyal dan keterjangkauan sinya pada seluruh pelosok daerah indonesia, karena tidak semua peserta didik tinggal didaerah kota yang mudah menjangkau sinyal

3) Pemerataan sosialisasi mengenai penggunaan teknologi selam aproses daring agar semua pihak melek teknologi baik usia muda ataupun yang tua

4) Inovasi gaya belajar yang mampu menciptakan atmosfer belajar yang menyenangkan sehingga proses menyerap materi dapat belajar lancar dan tujuan pembelajaran tercapai

Dengan adanya proses Student Centered Learning ini diharapkan para mahasiswa yang mengikuti mata kuliah auditing mampu lebih kritis dan kreatif dalam mempelajari materi yang diajarkan dan memecahkan serta menganalisis kasus yang diberikan. Sesi diskusi dan tanya jawab yang dilakukan dengan model small group diharapkan mmapu merangsang kreatifitas mahasiswa untuk bekerja sama mempelajari hal - hal baru yang tidak diketahui dan memecahkan kasus-kasus auditing. Karena jika ada beberapa materi yang kurang difahami, maka para mahaisswa bisa slaing bertukar fikrian dan bertanya dengan teman satu kelompoknya yang faham, atau bertanya pada dosen pengampu yang nantinya akan mengarahkan para mahasiswa untuk menemukan jawaban yang benar. Jika digambarkan , maka proses belajar dengan metode Student Centered Learning dapat dilihat seperti dibawah ini: 


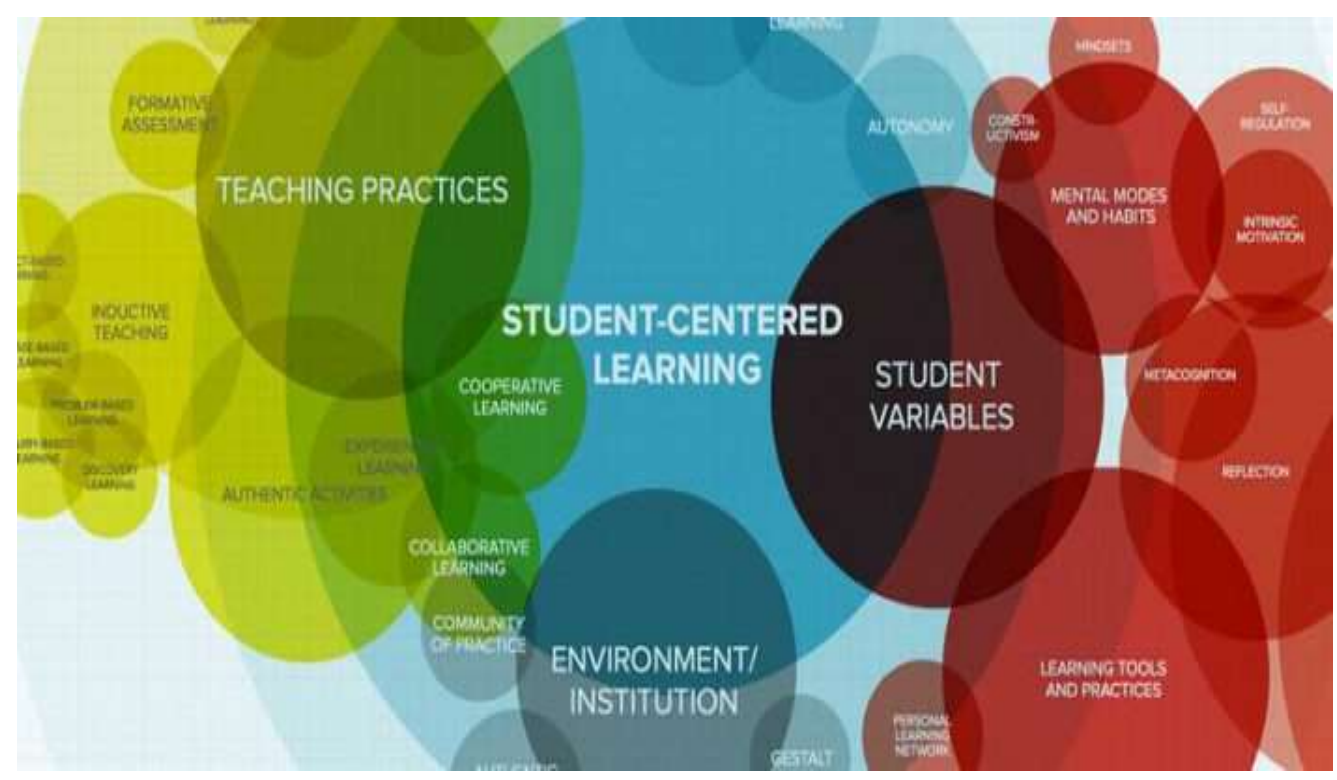

Gambar 3. Model pembelajaran Student Centered Learning

Dari visualisasi gambar diatas, maka dapat dilihat bahwasannya porsi dari Student Centered Learning jauh lebih besar dari aspek lainnya, atau dengan kata lain keaktifan dari mahasiswa lebih diutamakan dibandingkan penjelasan dosen dan lainnya.namun banyak variabel yang mendukung keberhasilan model pembelajaran ini selama daring :

1. Mahasiswa atau peserta didik

2. Tenaga Pendidik atau dosen

3. Fasilitas pembelajaran

4. Materi ajar

5. Mental dan fisik

6. Proses pembelajaran

7. Pemerintah

8. Waktu belajar

9. Dukungan Materi dan orang tua

10. Gaya mengajar

\section{KESIMPULAN}

\section{A. Kesimpulan}

Adapun kesimpulan dari hasil penelitian yang berjudul" Analisis Penerapan Model Pembelajaran Student Centered Learing Dengan Media Daring Pada Mata Kuliah Auditing (Studi Kasus Pada Mahasiswa Akuntansi Universitas Potensi Utama)"adalah sebagai berikut:

1) Proses pemebelajaran dengan media daring masih menemukan banyak kendala dalam penerapannya. Hal ini sudah tergambar jelas dalama hasil pembahasan pada penelitian ini.

2) Model pembelajaran Student Centered Learning dengan media daring mampu membuat suasana belajar lebih menyenangkan dan menstimulasi keaktifan dan kreatifitas mahasiswa 


\section{B. Saran}

Untuk mengakhiri penulisan ini, penulis akan memberikan beberapa saran sebagai berikut :

1) Bagi para praktisi mengajar yang mengampu mata kuliah auditing untuk lebih mengeksplor atau mengolaborasi model pembelajaran Student Centered Learning dengan model pembelajaran lain jika memungkinkan.

2) Perlu ada peningkatan dalam proses belajar daring didunia pendidikan degan adanya dukungan fasilitas yang lebih memadai seperti sinyal dan kuota yang mencukupi dari pemerintah.

\section{DAFTAR PUSTAKA}

[1] Adhe, Kartika Rinakit. 2018. Model Pembelajaran Daring Matakuliah Kajian PAUD di Jurusan PG PAUD Fakultas Ilmu Pendidikan Universitas Negeri Surabaya. Journal of Early Childhood Care \& Education (JECCE). Yogyakarta 3 April 2018

[2] Aipni.2012. Pengarug Metode Pembelajaran Dengan Pendekatan SCL (Student Centered Learning) Terhadap Motivasi Belajar Mahasis wa.Jurnal.Padang: Man ejemen Informatika.

[3] Aipni.2013. Pengarug Metode Pembelajaran Dengan Pendekatan SCL (Student Centered Learning) Terhadap Motivasi Belajar Mahasis wa.Jurnal.Padang: Manejemen Informatika.

[4] Agoes, Sukrisno. 2012. Auditing (Petunjuk Praktis Pemeriksaan Akuntan oleh Akuntan Publik). Edisi 4. Jakarta: Salemba empat.

[5] Agoes, Sukrisno, dan Estralita Trisnawati. 2013. Akuntansi Perpajakan. Jakarta: Salemba empat.

[6] Agoes, Sukrisno. 2014. Auditing (Petunjuk Praktis Pemeriksaan oleh Akuntan Publik). Edisi 4. Jakarta: Salemba Empat.

[7] Arsyad.2006.Efektivitas Penggunaan Metode Pembelajaran SCL Berbasis Situs Jejaring Sosial Geschool Dalam Pembelajaran Tik Untuk Meningkatkan Hasil Belajar Siswa Kelas XI Di Sma Negeri 1 Depok.Skripsi.Yogyakarta:Universitas Negeri Yogyakarta.

[8] Azizah, Maryam Nur. 2011. Efektivitas Penggunaan Metode Pembelajaran Student Centered Learning Berbasis Classroom Blogging untuk Meningkatkan Hasil Belajar Sis wa SMA. Jakarta: UPI

[9] Fakhrurrazi. 2018. Hakikat Pembelajaran yang Efektif. Jurnal At-Tafkir. Volume XI No. 1 hal. 87

[10] Ghirardini, B. (2011). E-learning Methodologies. Germany: Federal Ministry of Food, Agriculture and Cunsomer Protection.

[11] Hamalik, Oemar.2007.Proses Belajar Mengajar. Jakarta: PT Bumi Aksara.

[12] Hamalik, Oemar. 2014.Proses Belajar Mengajar. Jakarta: PT Bumi Aksara

[13] Ikatan Akuntan Indonesia(IAI).2001.Standard Profesional Akuntan Publik. Jakarta:Salemba Empat

[14] Mulyadi. 2002. Auditing (Buku1). Edisi keenam. Jakarta : Salemba Empat.

[15] Prabowo, Tommy. 2000. Klien Itupun Tak Memenuhi Syarat. Media A kuntansi No 10/TH, VII/Juni. Hal 57-58.

[16] Priyatmojo, Achmadi., dkk. 2010. Buku Panduan Pelaksanaan Students Centered Learning (SCL) dan Teacher Aesthethic Role-Sharing (STAR). Yogyakarta: Pusat Pengembangan Pendidikan Universitas Gadjah Mada

[17] Santoso, Singgih. 2002. Buku Latihan SPSS Statistik Parametik. Jakarta : PT Elex Media Komputindo. 
[18] Sarwono, Jonathan. 2006. Analisis Data Penelitian Menggunakan SPSS 13. Bandung: Penerbit Andi Yogyakarta.

[19] Suharto, Henry. 2000. Memahami Bisnis Klien : Berarti Memperkecil Resiko Audit. Media Akuntansi No 6/Th, I/Februari. Hal 40.

[20] Sugiyono.2017. Metode Penelitian Kuantitatif, Kualitatif dan Kombinasi (Mixed Methods), Cetakan Ke-9, (Bandung: ALFABETA, hal, 208.

[21] Sugiyono, 2014. Metodologi Penelitian Kuantitatif Kualitatif dan R\&D, Bandung: Alfabeta.

[22] Sardiman.2007.Interaksi Dan Motivasi Belajar-Mengajar.jakarta: PT Raja Grafindo Persada.

[23] Trinova.Z.2013. Pembelajaran Berbasis Student Centered Learning Pada Materi pendidikan Agama Islam. Jurnal Al-Ta'lim IAIN Imam Bonjol Padang

[24] Weswood Peter.2008.Student Centered Learning.Jurnal.Yogyakarta:Universitas Negeri Yogyakarta. 